\title{
STABILITAS STRUKTUR DAN SISTEM SAMBUNGAN PADA PLATFORM RUMAH APUNG DENGAN BAHAN EXPANDED POLYSTYRENE / STYROFOAM
}

\author{
Henny Pratiwi Adi \\ Program Studi Teknik Sipil, Universitas Islam Sultan Agung, Jl. Raya Kaligawe Km.4 Semarang \\ E-mail Koresponding : henni@unissula.ac.id
}

\begin{abstract}
Flooding due to rising sea levels is the most common problem in Semarang city, especially in coastal areas. This flood can be prevented or minimized its impact, one way is to build a floating house. This study aims to analyze the use of Expanded Polystyrene (EPS) or styrofoam as a floating home platform. The building that was designed was a building that functioned as a residential house with an area of $85 \mathrm{~m}^{2}$ using light steel material as a component of the upper structure, wood material as a sloof structure, floors and walls and styrofoam as a platform material. The analysis shows the total weight of the upper structure and platform structure $(G)$ of 555,887.5 Newton with a safety factor of 1.2. The strength of the buoyant force ( $F a)$ of the platform structure using Styrofoam is equal to 588,000 Newton. The connection system on the floating house platform is a bolt connection system, $3 \mathrm{~cm}$ in diameter with a length of $22 \mathrm{~cm}$ anchor totaling 4 bolts on each connection. The connection between the filling materials can use Styrofoam glue and then arranged and made one unit with the platform frame.
\end{abstract}

Keywords : floating house, platform, styrofoam

\begin{abstract}
ABSTRAK
Banjir akibat kenaikan muka air laut merupakan masalah yang paling sering terjadi di Kota Semarang, terutama di wilayah pesisir. Banjir ini dapat dicegah atau diminimalisir dampaknya, salah satu cara adalah dengan membangun rumah apung. Penelitian ini bertujuan untuk menganalisis penggunaan Expanded Polystyrene (EPS) atau styrofoam sebagai platform rumah apung. Bangunan yang didesain merupakan bangunan yang difungsikan sebagai rumah tinggal dengan luas bangunan $85 \mathrm{~m}^{2}$ dengan menggunakan bahan material baja ringan sebagai komponen struktur atas, material kayu sebagai struktur sloof, lantai dan dinding serta styrofoam sebagai material platform. Hasil analisis total berat struktur atas dan struktur platform (G) sebesar 555.887,5 Newton dengan safety factor 1,2. Kekuatan gaya apung (Fa) struktur palatform dengan menggunakan material styrofoam yaitu sebesar 588.000 Newton. Sistem sambungan pada rangka platform rumah apung merupakan sistem sambungan baut, berdiameter $3 \mathrm{~cm}$ dengan panjang angkur $22 \mathrm{~cm}$ berjumlah 4 baut pada setiap sambungan. Sambungan antara material pengisinya dapat menggunakan lem styrofoam kemudian disusun dan dibuat satu kesatuan dengan rangka platformnya.
\end{abstract}

Kata kunci : rumah apung, platform, styrofoam 


\section{PENDAHULUAN}

Semarang merupakan kota pesisir yang memiliki permasalahan banjir, Banjir yang sering terjadi, disebabkan oleh adanya air laut pasang yang lebih populer disebut rob (Adi \& Wahyudi, 2018). Banjir rob adalah banjir akibat muka air laut sama dengan atau bahkan melebihi tinggi elevasinya terhadap suatu daerah, sehingga pada waktu pasang terjadi genangan, baik di aliran sungai maupun pada daerah rendah (Adi \& Wahyudi, 2015). Banjir dan rob dapat dicegah atau di minimalisir dampaknya, salah satu caranya adalah dengan membangun rumah apung (floating house). Kelebihan rumah apung ini adalah fleksibilitas untuk berpindah posisi maupun lokasi. Selain itu, rumah yang yang menggunakan landasan datar bisa berotasi mengubah arah posisi rumah dan dapat berpindah (Santosa, W, S, Prabowo, \& Dwinanda, 2017). Selain ramah lingkungan dan anti banjir, rumah apung juga dinilai unik dari segi desain dan sustainable. Lokasi studi dalam penelitian ini adalah di kawasan pesisir utara Kota Semarang Indonesia, Pada wilayah tersebut telah dibangun pemecah gelombang dan tanggul laut, sehingga kawasan pesisir cukup terlindung dari energi gelombang laut, sehingga cukup aman untuk dibangun rumah apung (Adi, Wahyudi, \& Sudarmono, 2020).

Ada berbagai macam material yang dapat digunakan sebagai bahan platforms rumah apung, seperti bamboo, Styrofoam, pipa PVC dan drum plastik (Asrasal, Wahyudi, Adi, \& Heikoop, 2018). Penelitian ini bertujuan untuk menganalisis penggunaan Expanded Polystyrene (EPS) atau yang dikenal juga dengan nama styrofoam sebagai platform rumah apung. Adapun analisis dilakukan pada suatu konstruksi rumah apung sederhana dengan meliputi perhitungan pembebanan, daya apung serta sistem sambungan. Desain rumah apung dibuat sederhana yang bisa di aplikasikan sebagai rumah penduduk di kawasan pesisir pantai dengan mempertimbangkan desain yang ekonomis.

\section{METODE PENELITIAN}

Dalam penelitian ini, bangunan yang akan didesain merupakan bangunan yang difungsikan sebagai rumah tinggal dengan luas bangunan $85 \mathrm{~m}^{2}$ dengan menggunakan bahan material baja ringan sebagai komponen struktur atas, material kayu sebagai struktur sloof, lantai dan dinding serta styrofoam sebagai material platform. Pendekatan kuantitatif dipergunakan untuk mengukur data berupa angka berkenaan dengan keadaan struktur platform 
rumah apung, struktur atas serta gaya-gaya yang terjadi, bersifat faktual dan akurat. Adapun perhitungan dan analisis yang dilakukan meliputi :

a. Analisis keseimbangan material platform rumah apung terhadap beban diatasnya

b. Analisis berat struktur atas (sloof, kolom, ringbalok dan rangka kuda - kuda) terhadap gaya-gaya yang bekerja menggunakan Software SAP2000 V.16.

c. Analisis sambungan pada struktur platform.

\subsection{Rumah Apung}

Rumah apung, merupakan konsep rumah tinggal atau bersinggah dengan menggunakan media struktur apung. Konsep struktur terapung atau yang sering disebut 'Floating Structure' yang digunakan sebagai pengganti tanah dalam pembangunan sebuah bangunan. selain menjadi alternatif prearrangement wilayah disamping reklamasi, karena strukturnya mampu mengapung diatas air (Pribadi, 2011). Dalam konsep struktur terapung ini, secara umum terdapat perbedaan yang sangat mendasar dibandingkan proses pembangunan struktur bangunan di darat.Struktur bangunan darat, proses pembangunannya sejak tahap awal hingga akhir dilakukan di tempat yang sama. Sebaliknya, struktur terapung, apapun jenisnya dibangun atau difabrikasi di tempat yang berbeda dengan di tempat instalasinya (knock-down) (Halim, 2013). Perbedaan kondisi inilah yang menyebabkan perbedaan proses pembangunan dan teknologi yang diperlukan dalam aplikasinya. Ada dua tipe dari struktur terapung, yaitu tipe semisubmersible dan pontoon (Watanabe, C.M. Wang, 2004).

a. Tipe semisubmersible, adalah membangun struktur terapung dia atas permukaan air laut dengan menggunakan column tubes atau elemen struktur ballast untuk meminimalkan efek gelombang dan menjadikannya agar tetap terapung. Tipe struktur ini dapat diaplikasikan pada anjungan lepas pantai, sepeti semisubmersible dan tension leg platforms.

b. Tipe pontoon merupakan struktur terapung yang sering ditemui pada beberapa pelabuhan biasanya ditempatkan pada wilayah yang mempunyai perairan cukup tenang, seperti teluk. Dari sisi konstruksi, aplikasi struktur terapung jauh lebih efisien karena tidak perlu pembuatan dan pengerjaan desain pondasi konvensional seperti tiang pancang dan sejenisnya. Konstruksi mengapung ini hanya diikat dengan mooring system dengan seabed. 
Dewasa ini dan di masa depan, diperkirakan struktur bangunan terapung akan menjadi primadona konstruksi.. Keuntungannya adalah tidak menimbulkan scouring pada pondasi pilar sebagai penumpu bangunan. Pilar konvensional umumnya mengalami masalah scouring atau gerusan yang dapat membahayakan pondasi struktur. Keuntungan dari penggunaan floating structure (Cahya, Mahardika, \& Wp, 2017) adalah sebagai berikut :

a. Efisiensi konstruksi karena tidak perlu pembuatan dan pengerjaan desain pondasi

b. Ramah lingkungan karena tidak merusak dan tidak menambah volume benda yang bersifat massive structure.

c. Mudah dan cepat dalam pengerjaan karena proses pengerjaan dengan metode perakitan (assembling method).

d. Tahan terhadap gempa karena secara struktur tidak tertanam di tanah atau tidak berbasis pondasi namun mengapung dan hanya di ikat dengan mooring.

e. Mudah dipindah maupun diperbaiki karena sifatnya yang dapat dirakit (assembling method).

f. Konstruksi apung tidak mengalami proses konsolidasi maupun setlemen.

g. Cocok untuk pembuatan konstruksi yang mengedepankan estetika model atau bentuk dibandingkan metode konvensional .

\subsection{Expanded Polystyrene / Styrofoam}

Rumah anti banjir dapat diwujudkan melalui konsep rumah apung, rumah akan mengapung bila terjadi banjir sehingga air tidak dapat menggenangi rumah ketika terjadi bajir. Oleh sebab itu, pengapung merupakan salah satu bahan bangunan yang sangat penting bagi rumah apung (Ishaque, Ahamed, \& Hoque, 2014). Sehingga beban mati dan hidup yang ada di dalam rumah dapat terangkat. Untuk memperingan beban angkat pada rumah, material bangunan perlu diperhatikan (Adi et al., 2020). Terutama dinding dan lantai bata ringan yang dapat diminimalisir bebannya. EPS (Expandable Polystrene) atau gabus putih / styrofoam merupakan salah satu material yang dapat digunakan sebagai pengganti plat lantai (Santosa et al., 2017). Keunggulan EPS adalah :

1. Lebih ringan : panel EPS standar hanya kurang lebih $40 \mathrm{~kg}(1 / 4 \mathrm{kali}$ dari bobot berat bata ringan yang umumnya beredar), dan Panel EPS Composite hanya kurang lebih $90 \mathrm{~kg}$ (hanya sekitar $1 / 2$ kali dari bobot berat bata ringan yang umum beredar). Dengan bobot 
seperti ini, ketebalan struktur utama bangunan dapat dikurangi dan menghasilkan ruang dalam yang lebih luas. Panel EPS terhadap benturan, panas, tekanan teruji secara teknis. Karena terdiri dari lapisan dalam styrofoam dengan lapisan luar fiber-semen dan untuk Panel EPS Composite terdiri dari butiran styrofoam dan semen yang dipadatkan dengan tekanan tinggi dengan lapisan luar magnesium oxide.

3. Awet / tahan lama : panel EPS memiliki daya tahan terhadap panas, lembab, dan guncangan, oleh karena itu dinding yang dibangun dengan Panel EPS awet, stabil, dan tahan lama.

4. Presisi : ukuran panel EPS terstandar secara akurat $60 \mathrm{~cm}$ x $295 \mathrm{~cm}$ dengan variasi ketebalan $8 \mathrm{~cm}, 10 \mathrm{~cm}$, dan $12 \mathrm{~cm}$.

5. Tahan tekanan : panel EPS dengan tebal $10 \mathrm{~cm}$ mampu menahan bobot sampai $2500 \mathrm{~kg}$, sedangkan bobot horizontal bisa sampai $4500 \mathrm{~kg}$

6. Ramah lingkungan : bahan-bahan/ material yang digunakan untuk membuat Panel EPS tidak mengandung polutan, zat kimia dan zat radioaktif yang dapat berbahaya bagi kehidupan.

7. Kedap air : panel EPS tahan terhadap air dan bersifat isolative terhadap air, sehingga tidak akan ada dinding Panel EPS yang lembab, berjamur, dan terkelupas catnya.

8. Isolasi suhu / temperatur : panel EPS bersifat isolator terhadap panas maupun dingin, dengan demukian penggunaan $\mathrm{AC}$ dalam ruangan yang menggunakan panel EPS lebih hemat energi.

9. Ekonomis dan efisien panel EPS hanya sedikit mortar dan bisa langsung dicat.Untuk bobot kontruksi secara keseluruhan juga lebih ringan sehingga menghemat struktur. Pengerjaannya yang mudah sekali juga akan menghemat waktu dan tenaga kerja.

\section{HASIL DAN PEMBAHASAN}

Data bangunan merupakan data informasi yang menjelaskan bentuk, luasan dan fungsi bangunan yang akan di desain. Dalam analisis ini data bangunan sepenuhnya direncanakan oleh peneliti. Data material bangunan yaitu data mengenai material yang akan digunakan sebagai komponen struktur rumah apung yang terdiri dari struktur atas (up struktur) dan struktur bawah (sub struktur) berupa platform. 


\subsection{Desain Bangunan}

Data bangunan sepenuhnya direncanakan (ditentukan) oleh peneliti, diantaranya adalah sebagai berikut :

Nama bangunan : Rumah Apung (Floating House)

Fungsi Bangunan : Rumah Tinggal

Luasan Bangunan: $8 \mathrm{~m}$ x $10 \mathrm{~m}\left(80 \mathrm{~m}^{2}\right)$

Tinggi Bangunan : 3,5 m (Struktur Sloof - Ringbalok)

: 2,5 m (Struktur kuda-kuda)

Jumlah lantai : 1 lantai

Jenis Pondasi : Platform (Styrofoam)

Sistem pondasi : Mengapung

Penjelasan lebih detail, dapat dilihat pada Gambar 1 dan Gambar 2 di bawah ini.

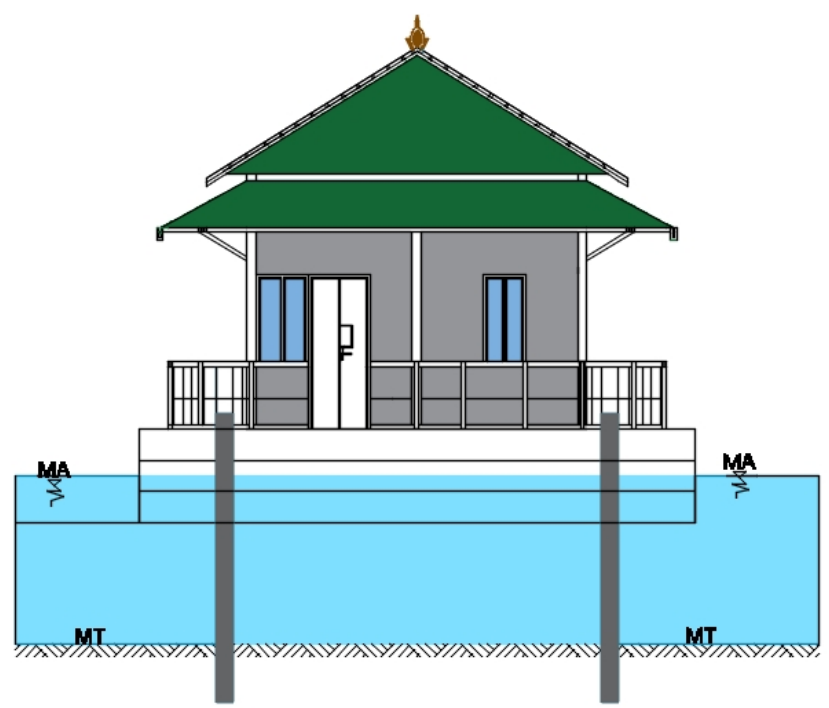

Gambar 1. Tampak Depan 


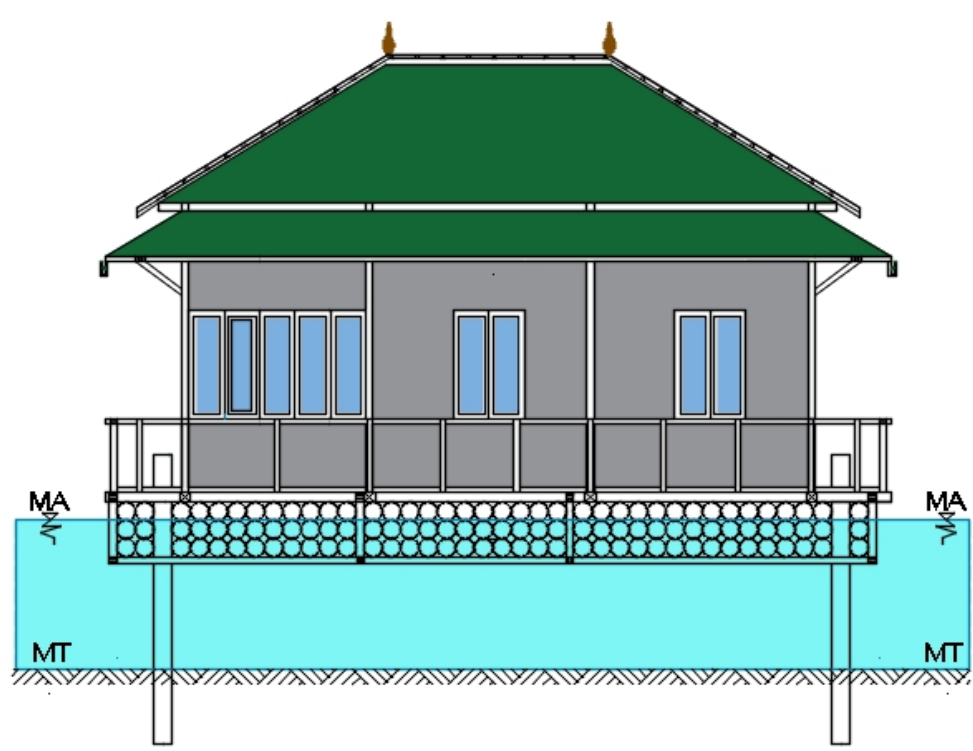

\section{a. Struktur Atas}

Gambar. 2 Tampak Samping

Data struktur atas merupakan data dari komponen struktur bangunan yang terdiri dari beberapa jenis material diantaranya adalah sebagai berikut:

- Struktur Sloof

Dimensi

Jenis kayu

Kelas kuat kayu

Berat jenis
$: 15 \mathrm{~cm} \mathrm{x} 15 \mathrm{~cm}$

: Ulin

: Kelas I

: $900 \mathrm{~kg} / \mathrm{m}^{3}$

Kuat tarik sejajae serat : $<650 \mathrm{~kg} / \mathrm{cm}^{2}$ (absolut), $130 \mathrm{~kg} / \mathrm{cm}^{2}$ (ijin)

Kuat tekan lentur $\quad:<1100 \mathrm{~kg} / \mathrm{cm}^{2}$ (absolut), $150 \mathrm{~kg} / \mathrm{cm}^{2}$ (ijin)

- Struktur Kolom

Profil

Jenis Baja

Berat jenis

Kuat tarik

Modulus elastisitas

Modulus Geser
: I. $150 \mathrm{~mm} \times 150 \mathrm{~mm} \times 50 \mathrm{~mm}$

: Baja Ringan (galvalum)

$: 7850 \mathrm{~kg} / \mathrm{m}^{3}$

: $550 \mathrm{mpa}$

: 2,1 $105 \mathrm{mpa}$

: 8 x $104 \mathrm{mpa}$

- Struktur Ringbalok

Profil

: I. $150 \mathrm{~mm} \times 150 \mathrm{~mm} \times 50 \mathrm{~mm}$ 
Jenis Baja : Baja Ringan (galvalum)

Berat jenis $\quad: 7400 \mathrm{~kg} / \mathrm{m}^{3}$

Kuat tarik $\quad: 550 \mathrm{Mpa}$

Modulus elestisitas $\quad: 200.000 \mathrm{mpa}$

Modulus geser $\quad: 80.000 \mathrm{mpa}$

- Dinding

Jenis $\quad$ : Partisi (Clash Board)

Tebal $\quad: 10 \mathrm{~cm}$

Berat $\quad: 40 \mathrm{~kg} / \mathrm{m}^{2}$

- Struktur Kuda-Kuda

$\begin{array}{ll}\text { Profil } & : \text { C. } 50 \times 50 \times 6 \\ \text { Jenis Baja } & : \text { Baja Ringan (Canai) } \\ \text { Berat jenis } & : 7400 \mathrm{~kg} / \mathrm{m}^{3} \\ \text { Kuat tarik } & : 550 \mathrm{mpa} \\ \text { Modulus elastisitas } & : 200.000 \mathrm{mpa} \\ \text { Modulus Geser } & : 80.000 \mathrm{mpa} \\ \text { Reng } & : 4 \mathrm{~cm} \\ \text { Gording } & : \text { C. } 50 \times 50 \times 5 \\ \text { Atap } & : \text { Sakura }\end{array}$

\section{b. Struktur Bawah}

Data struktur bawah merupakan data dari komponen platform yang terdiri beberapa jenis material yang memiliki daya apung cukup besar diantaranya adalah sebagai berikut:

- Material Platform Pipa PVC

Panjang $\quad: 6 \mathrm{~m}$

Diameter : :12 inch $(2,5 \times 12=30 \mathrm{~cm})$

Berat $\quad: 1,42 \mathrm{~kg} / \mathrm{m}^{2}$

Tebal $\quad: 1,1 \mathrm{~cm}$

Jenis $\quad$ : SLG Standar (AW)

- Material Platform Bambu

Panjan $\quad: 5 \mathrm{~m}$ 
Diameter $\quad: 5$ inch $(2,5 \times 5=10 \mathrm{~cm})$

Berat $\quad: 3 \mathrm{~kg} / \mathrm{m}$ (Kering)

Jenis : Bambu galah

Kuat tarik : Pangkal (192 Mpa), tengah (235 Mpa), ujung (232 Mpa)

Kuat tekan : Pangkal (327 Mpa), tengah (399 Mpa), ujung (405 Mpa)

- Material Platform Styrofoam

$\begin{array}{ll}\text { Panjan } & : 3 \mathrm{~m} \\ \text { Lebar } & : 2 \mathrm{~m} \\ \text { Tinggi } & : 0,6 \mathrm{~m} \\ \text { Berat } & : 20 \mathrm{~kg} / \mathrm{m}^{2}\end{array}$

- Alat Penyambung

- Baut

Diameter $: 3 \mathrm{~cm}$

- Angkur

Diameter : $2,8 \mathrm{~cm}$

Panjang : $22 \mathrm{~cm}$

\subsection{Analisis Pembebanan Struktur}

Pembebanan struktur terdiri dari beban mati (Dead Load) adalah beban yang berasal dari komponen atau atribut bangunan yang tidak dapat berpindah-pindah. Beban hidup (live load) berupa orang atau barang yang dapat berpindah-pindah. Beban angin (wind load) merupakan beban yang terjadi akibat tekanan berdasrkan kecepatan angin di derah tersebut. Analisis beban yang di terima oleh struktur rumah apung dapat dibagi menjadi dua yaitu, pembebanan pada struktur atas yang terdiri dari (Beban mati, beban hidup dan beban angin) dan pembebanan pada struktur paltform yang terdiri dari (Beban mati dan beban hidup) yang berasal dari berat rangka paltform, alat penyambung dan material Styrofoam adalah sebagai berikut:

\subsubsection{Pembebanan Pada Struktur Atas}

\section{a. Beban mati (Dead load)}

Beban mati pada plat lantai $\quad: 125 \mathrm{~kg} / \mathrm{m}^{2}$ 
Beban mati dinding

Beban mati rangka atap

Total

\section{b. Beban hidup (Live load)}

Beban hidup di plat lantai

Beban hidup pada rangka atap

\section{c. Beban angin (wind load)}

Beban angin
: $40 \mathrm{~kg} / \mathrm{m}^{2}(40 \times 3,5)$

: $140 \mathrm{~kg} / \mathrm{m}^{2}$

: Atap skura poof $=1,5 \mathrm{~kg} / \mathrm{m}^{2}$

Reng PD. $40=3,89 \mathrm{~kg} / \mathrm{m}^{2}$ (Galvalume)

: $5,39 \mathrm{~kg} / \mathrm{m}^{2}$

: $100 \mathrm{~kg} / \mathrm{m}^{2}$

: $80 \mathrm{~kg}$ (Beban pekerja+perkakas)

Selanjutnya beban yang diperoleh di input dan di analisis menggunakan software SAP2000 V.16 dengan maksud untuk mengetahui berat struktur secara total hingga gaya-gaya yang ditimbulkan akibat reaksi beban, sehingga dapat digunakan sebagai parameter menghitung gaya apung $(\mathrm{Fa})$ dan kekuatan sambungan pada struktur platform rumah apung. Berdasarkan hasil analisis software SAP2000 diperoleh berat total struktur atas sebagai berikut.

Tabel 1 Base reaction Stuktur

\begin{tabular}{|c|c|c|c|c|c|c|c|c|c|}
\hline & $\begin{array}{c}\text { OutputCase } \\
\text { Text }\end{array}$ & $\begin{array}{c}\text { CaseType } \\
\text { Text }\end{array}$ & $\begin{array}{c}\text { StepType } \\
\text { Text }\end{array}$ & $\begin{array}{r}\text { GlobalFX } \\
\mathrm{Kgf}\end{array}$ & $\begin{array}{r}\text { GlobalFY } \\
\text { Kgf }\end{array}$ & $\begin{array}{r}\text { GlobalFZ } \\
\mathrm{Kgf}\end{array}$ & $\begin{array}{r}\begin{array}{r}\text { GloballMX } \\
\text { Kgf-m }\end{array} \\
\end{array}$ & $\begin{array}{r}\text { GlobalMY } \\
\text { Kgf-m }\end{array}$ & $\begin{array}{r}\text { GlobalMZ } \\
\text { Kgf-m } \\
\end{array}$ \\
\hline 1 & COMB ALL & Combination & Max & 0,0000002104 & $-0,0000002335$ & 44557,8 & 289620,02 & $-15524,59$ & 0,00000001736 \\
\hline & COMB ALL & Combination & Min & -40 & $-2900,26$ & 21610.35 & 140462,99 & $-32102,7$ & $-2324,19$ \\
\hline
\end{tabular}

(Sumber: Hasil analisis SAP2000)

Total berat struktur akibat beban yang bekerja $=44557,8$

$$
\begin{aligned}
& =44557,8 \times 10 \\
& =445578 \text { Newton }
\end{aligned}
$$

\subsubsection{Pembebanan Struktur Bawah}

Beban platform terdiri dari beban hidup dan beban mati. Beban hidup (live load) berupa orang atau barang yang dapat berpindah-pindah. Beban mati (Dead load) berupa beban yang berasal dari rangka dan lantai platform yang tidak dapat berpindah-pindah. Analisis beban hidup di input berdasarkan kapasitas tampungan dermaga yang akan direncanakan.

\section{a. Beban Hidup (Live Load)}

$$
\text { Peban Pekerja }
$$

$$
=40 \mathrm{rang}
$$


Berat perorang

$$
\begin{aligned}
& =80 \mathrm{~kg} \text { (asumsi) } \\
& =320 \mathrm{~kg}
\end{aligned}
$$

\section{b. Beban Mati (Dead Load)}

\section{Berat Rangka Platform}

- Balok Kayu (horizontal) $=8 / 12$

\begin{tabular}{|c|c|c|c|c|c|c|c|}
\hline \multirow{2}{*}{$\begin{array}{l}\text { Kelas } \\
\text { Kuat }\end{array}$} & \multirow{2}{*}{$\begin{array}{l}\text { Berat } \\
\text { Jenis }\end{array}$} & \multicolumn{2}{|c|}{$\begin{array}{l}\text { Tekan-Tarik // } \\
\text { Serat Kg/cm }\end{array}$} & \multicolumn{2}{|c|}{$\begin{array}{c}\text { Tarik } \underset{\mathrm{Kg} / \mathrm{cm}^{2}}{\perp} \text { Seat } \\
\end{array}$} & \multicolumn{2}{|c|}{$\begin{array}{l}\text { Kuat Lentur } \\
\mathrm{Kg}^{\prime} \mathrm{cm}^{2}\end{array}$} \\
\hline & & Absolut & ljin & Absolut & lij & Absolut & ljin \\
\hline I & $\geq 0.900$ & $>650$ & 130 & & 20 & $>1100$ & 150 \\
\hline II & $0.60-0.90$ & $425-650$ & 85 & & 12 & $725-1100$ & 100 \\
\hline IIII & $0.40-0.60$ & $300-425$ & 60 & & 8 & $500-725$ & 75 \\
\hline $\mathrm{N}$ & $0.30-0.40$ & $215-300$ & 45 & & 5 & $360-500$ & 50 \\
\hline $\bar{V}$ & $\leq 0.300$ & $<215$ & - & & - & $<360$ & - \\
\hline
\end{tabular}

Tabel 2. Kelas kuat dan berat jenis Kayu

(Sumber :PKKI - 1979)

Beraj Jenis Kayu

Berat Kayu

- Balok Kayu (vertikal)

Beraj Jenis Kayu

Berat Kayu

- Papan Kayu

Berat Kayu

- Alat Penyambung (Baut)

- Baut

Jumlah

Berat

- Angkur

Panjang

Jumlah

$$
=0,900 \mathrm{~kg} / \mathrm{cm}^{2} \rightarrow 900 \mathrm{~kg} / \mathrm{m}^{3}
$$

$=$ Volume $\mathrm{x}$ BJ

$$
=0,307 \times 900=276,48 \mathrm{~kg}
$$

$=8 / 12$

$=0,900 \mathrm{~kg} / \mathrm{cm}^{2} \rightarrow 900 \mathrm{~kg} / \mathrm{m}^{3}$

$=$ Volume $\mathrm{x} \mathrm{BJ}$

$$
=0,115 \times 900=107,68 \mathrm{~kg}
$$

$=2 / 20$

$=$ Volume $\mathrm{x}$ BJ $\left(\right.$ kayu kelas $\mathrm{I}=900 \mathrm{~kg} / \mathrm{m}^{3}$ )

$$
=1,116 \times 900=1004,4 \mathrm{~kg}
$$




$$
\begin{array}{ll}
\text { Berat } & =0,7 \mathrm{~kg} / \text { angkur } \\
& =0,7 \times 48=33,6 \mathrm{~kg} \\
\text { Total dead load } & =\underline{276,48+107,68+1004,4+24+33,6} \\
& =1446,16 \mathrm{~kg} \\
\text { Total beban yang bekerja } & =\text { live load }+ \text { dead load } \\
& =320+1446,16
\end{array}
$$

\subsection{Analisis Gaya Apung Platform}

Analisis gaya apung $(\mathrm{Fa})$ merupakan analisis besaran gaya apung suatu material paltform yang akan dibandingakan dengan gaya kebawah akibat berat struktur rumah apung. Platform dikatakan kuat apabila gaya ke atas (Fa) lebih beasar dari total berat struktur (G). Berikut merupakan gaya apung material platform berbahan styrofoam.

\section{a. Apabila Styrofoam Seluruhnya Tenggelam}

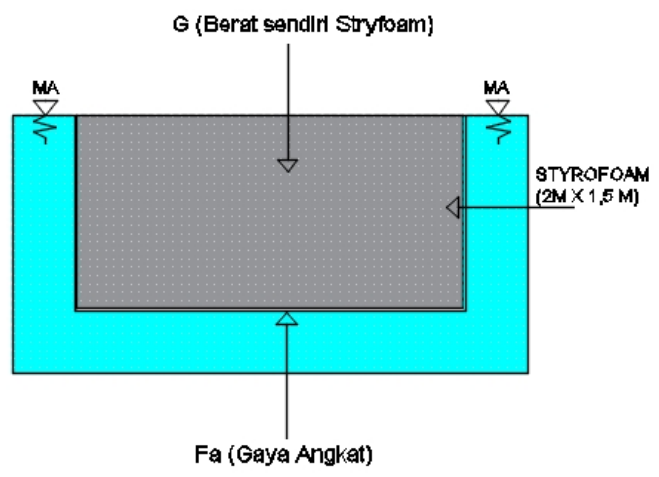

Gambar 3. Gaya Apung Styrofoam Dengan Seluruhnya Tenggelam

$$
\begin{aligned}
\text { Berat sendiri styrofoam }(\mathrm{G}) & =\mathrm{kg} \times \mathrm{g} \\
& =200 \times 10=2.000 \text { Newton } \\
& =\text { T.P.p.g.L } \\
& =0,5 \times 2 \times 1000 \times 10 \times 1 \\
& =10.000 \text { Newton/baris }
\end{aligned}
$$

Jadi gaya apung total adalah $=\mathrm{V}-\mathrm{G}$

$$
=10.000-2.000
$$




$$
\begin{array}{ll} 
& =9.800 \text { Newton/ batang (arah keatas) } \\
\text { Gaya apung } 1 \text { lapis (15 batang) } & =15 \times 9800 \\
& =147.000 \\
\text { Gaya apung untuk } 4 \text { lapis } & =4 \times 147.000 \\
& =588.000 \text { Newton }
\end{array}
$$

\section{a. Analisis Kestabilan Struktur}

Struktur dikatakan stabil apabila gaya apung (Fa) lebih besar dari berat total struktur rumah apaung $(\mathrm{G})$.

Berat Total struktur rumah apung $(\mathrm{G})=463.239,6$ Newton (Arah ke bawah)

$$
\mathrm{SF} \text { (angka keamanan) } \quad=1,2
$$

Gaya Apung Keatas $(\mathrm{Fa}) \quad=588000$ Newton (arah keatas)

$\mathrm{Fa}-(\mathrm{G} \times 1,2)$

$$
\begin{aligned}
& =588000-(463.239,6 \times 1,2) \\
& =32112,5 \text { Newton } \rightarrow \text { Ok }
\end{aligned}
$$

Jadi struktur platform rumah apung menggunakan material Styrofoam dibutuhkan jumlah Stryfoam sebanyak 60 batang dengan panjang 2 meter dan lebar 1 meter. Sistem pondasi dibuat 4 lapis dengan tinggi platform 2 meter seperti pada Gambar 4.4 dan Gambar 4.5 dibawah ini.

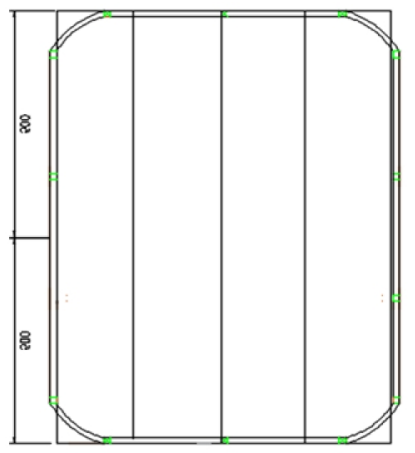

Gambar 4. Pola Penyusunan Platform Styrofoam 1-4 lapis 


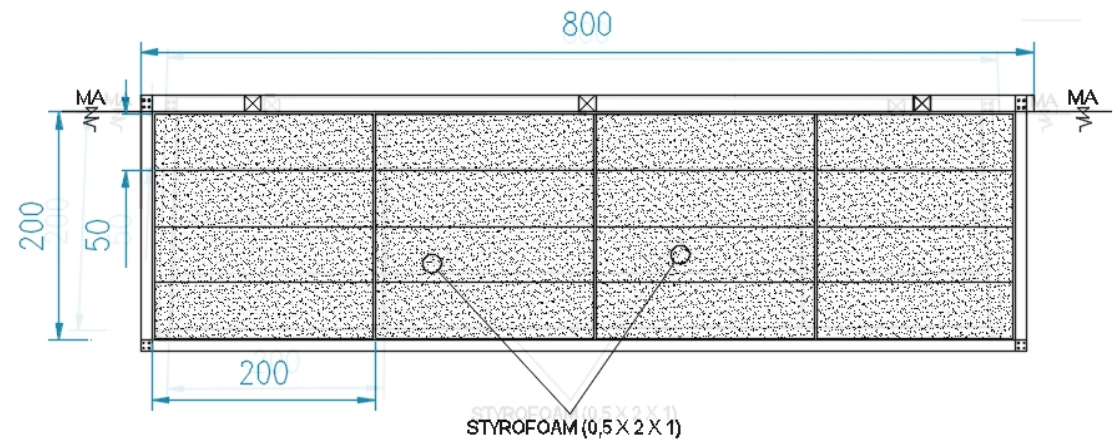

Gambar 5. Potongan Melintang Platform Styrofoam

\subsection{Analisis Sambungan Platform}

Material styrofoam dengan ukuran $0,5 \mathrm{~m} \times 2 \mathrm{~m} \times 1 \mathrm{~m}$ disusun 4 lapis dalam rangka paltform kemudian diperkuat dengan menggunakan alat penyambung baut. Berikut merupakan model sambungan platform menggunakan material Styrofoam.

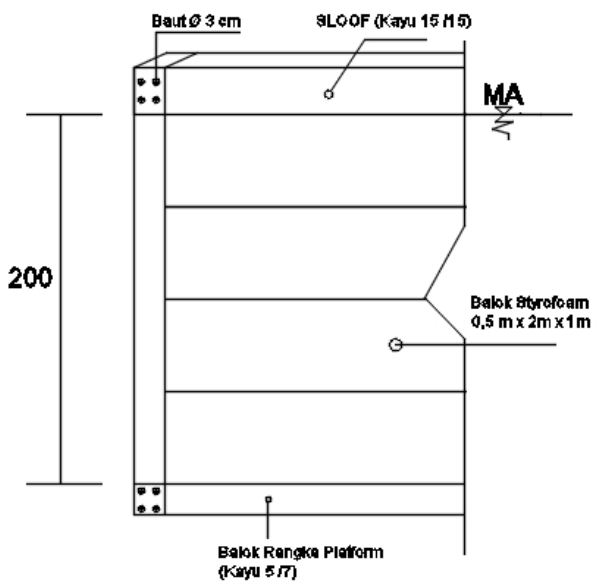

Gambar 6. Model Sambungan Platform Styrofoam (Pot.Melintang) 


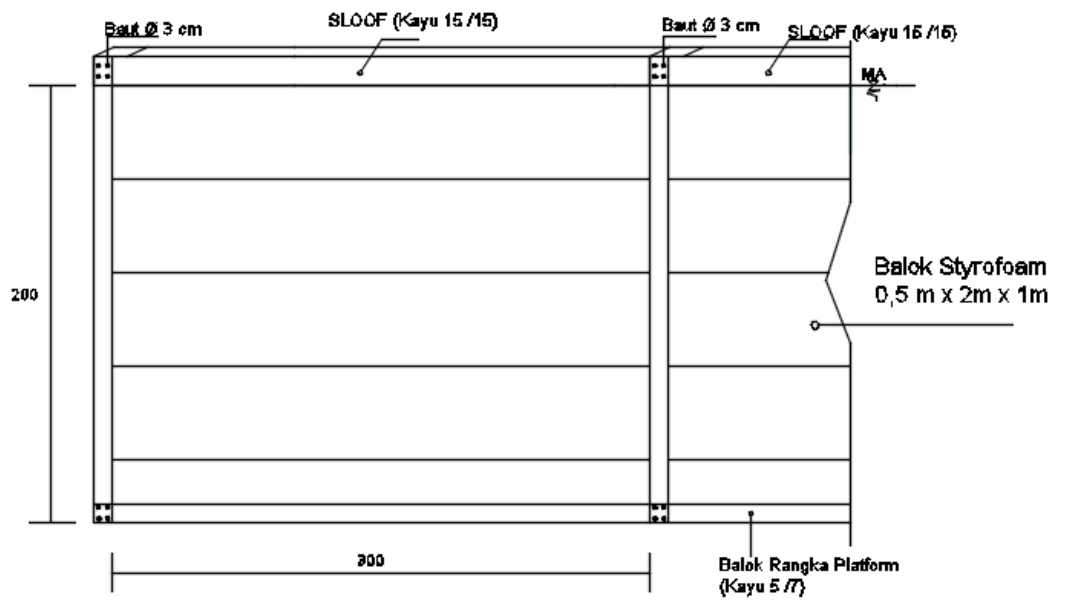

Gambar 7. Model Sambungan Platform Styrofoam (Pot.Memanjang)

\section{KESIMPULAN DAN SARAN}

\subsection{Kesimpulan}

Berdasarkan hasil analisis, selanjutnya dapat disimpulkan hal-hal sebagai berikut :

1. Penerapan konsep rumah apung merupakan upaya untuk memberikan solusi yang diinginkan oleh masyarakat dalam mengatasi dampak dari rob yang lebih efisien dan bertahan dalam jangka waktu yang panjang.

2. Hasil analisis total berat struktur atas dan struktur platform (G) yaitu sebesar 555.887,5 Newton dengan safety factor $(1,2)$. Kekuatan gaya apung (Fa) struktur palatform dengan menggunakan material Styrofoam yaitu sebesar 588.000 Newton.

3. Sistem sambungan pada rangka platform rumah apung merupakan sistem sambungan baut, berdiameter $3 \mathrm{~cm}$ dengan panjang angkur $22 \mathrm{~cm}$ berjumlah 4 baut pada setiap sambungan. Sambungan antara material pengisinya dapat menggunakan lem styrofoam kemudian disusun dan dibuat satu kesatuan dengan rangka platformnya.

\subsection{Saran}

Adapun saran yang dapat diberikan adalah sebagai berikut:

1. Untuk menambah daya apung platform, maka luasan dan tinggi platform dapat diperbesar. 
2. Untuk menambah keawetan dari material platform, pada material styrofoam dapat menggunakan bahan pelindung pada material styrofoam agar terhindar dari gangguan dari hewan laut (ikan).

\section{DAFTAR PUSTAKA}

Adi, H. P., \& Wahyudi, S. I. (2015, February). Study of Institutional Evaluation in Drainage System Management of Semarang as Delta City. In International Conference on Coastal and Delta Areas (Vol. 1, No. 1, pp. 129-135)..

Adi, H. P., \& Wahyudi, S. I. (2018). Tidal Flood Handling through Community Participation in Drainage Management System (A case study of the first water board in Indonesia). International Journal of Integrated Engineering, 10(2), 19-23. https://doi.org/https://doi.org/10.30880/ijie.2018.10.02.004

Adi, H. P., Wahyudi, S. I., Sudarmono, C. S., \& Islam, M. C. (2020, January). Comparison analysis of expanded polystyrene system (eps) and polyvinyl chloride (pvc) pipe as platform material of floating buildings in the coastal areas of Semarang. In Journal of Physics: Conference Series (Vol. 1444, No. 1, p. 012047). IOP Publishing.

Asrasal, A., Wahyudi, S. I., Adi, H. P., \& Heikoop, R. (2018). Analysis of floating house platform stability using polyvinyl chloride (PVC) pipe material. In MATEC Web of Conferences (Vol. 195, p. 02025). EDP Sciences.

Putra, D. C. M., \& Triwilaswandio, W. P. (2017). Analisa Teknis Dan Ekonomis Pengembangan Industri Rumah Apung Sebagai Pendukung Wisata Bahari Indonesia. Jurnal Teknik ITS, 6(2), G224-G229.

Halim, H. (2013). Structure System of Floating House at Tempe Lake in South Sulawesi. Jurnal Permukiman, 8(3), 145-152.

Ishaque, F., Ahamed, M. S., \& Hoque, M. N. (2014). Design and estimation of low cost floating house. International Journal of Innovation and Applied Studies, 7(1), 49.

Pribadi, S. B. (2011). Sistem Konstruksi Bangunan Sederhana Pada Perbaikan Rumah Warga di Daerah Rob ( Studi Kasus : Kelurahan Kemijen, Semarang Timur ). MODUL, 11(2), $81-88$

Santosa, D. E., W, B. A., S, V. F., Prabowo, I., \& Dwinanda, O. (2017). Rumah Amfibi sebagai Solusi Ekologis untuk Mengatasi Rob. In Prosiding Seminar Nasional Arsitektur Populis (pp. 27-39).

Watanabe, C.M. Wang, T. U. dan T. M. (2004). Very Large Floating Structures: Applications, Analysis And Design. Singapore: Centre for Offshore Research and Engineering National University of Singapore. 